\section{Performance of Hazelnut Cultivars from Oregon, Italy, and Spain, in Northeastern Spain}

\author{
Mercè Rovira ${ }^{1}$, Juan Francisco Hermoso, and Agustí J. Romero
}

AdDITIONAL INDEX wORDs. Corylus avellana, kernel quality, vigor, early bearing, sucker production, fatty acids, nutritional value

Summary. Eleven hazelnut (Corylus avellana) cultivars, four Spanish (Clon La Masó, Negret N-9, Negret Primerenc, and Pauetet), four Italian (San Giovanni, Tonda Italiana, Tonda di Giffoni, and Tonda Romana), and three cultivars from Oregon State University's (OSU) breeding program (Clark, Lewis, and Willamette), were evaluated in northeastern Spain over a period of 15 years (2001-14). The trial was planted at the Institute of Agriculture and Food Research and Technology (IRTA)-Mas de Bover Station (Constantí, Spain) in 2001, using own-rooted material, in single-trunk, $6 \times 3.5-\mathrm{m}$ spacing, and fitted with drip irrigation. Tree vigor, sucker production, early bearing, and total crop were recorded during the first 9 years. Nut traits were studied over 7 years and nutritional composition analyzed in 3 years. The best agronomic performance was observed in 'San Giovanni', 'Pauetet', 'Clon La Masó', and 'Tonda Italiana' that scored the highest total crop and canopy volume, but 'San Giovanni' and 'Clon La Masó' produced a high number of suckers. The best industrial value of the kernel was given by 'Tonda di Giffoni', 'Negret N-9', 'Willamette', and 'Clark' with high roasting aptitude and high fat content, although 'Negret N-9' was a little poor in monounsaturated fatty acids. The three cultivars from the Oregon breeding program had good agronomic behavior and industrial potential, but were not an improvement on the traditional Mediterranean cultivars.

$\mathrm{H}$ azelnut production worldwide was more than $700,000 \mathrm{t}$ in 2014. Turkey has the highest production with over $450,000 \mathrm{t}$, followed by Italy, Georgia, United States, Azerbaijan, China, Islamic Republic of Iran, and Spain. Spanish hazelnut production was about 13,500 t in 2014 (Food and Agriculture Organization of the United Nations, 2017).

The production area in Spain has decreased in the last 10 years, from 20,395 ha in 2004 to 13,591 ha in 2014 (Ministerio de Agricultura y Pesca, Alimentación y Medio Ambiente, 2017), mainly due to a drop in prices. The main Spanish cultivar is 'Negret', planted in $70 \%$ of commercial orchards (Tous et al., 2009). In the last 15 years, interesting cultivars from different countries, mainly Italy, have been introduced

Fruit Program-Institute of Agriculture and Food Research and Technology, Ctra. Reus-El Morell km 3,8 43120-Constantí, Tarragona, Spain

This research was supported by INIA (Spanish government) Projects (RF-01-036, RFP2004-0001100-00, RFP2009-0001300-00).

Authors are grateful to CERCA Programme/Generalitat the Catalunya for its support.

${ }^{1}$ Corresponding author. E-mail: merce.rovira@irta. cat.

doi: 10.21273/HORTTECH03705-17 in new orchards. Some of these materials have been studied in the cultivar collection at IRTA-Mas de Bover (Garcia et al., 1983; Tous and Rovira, 2004; Tous et al., 1987). However, the research here was to conduct a comparative trial of these Italian cultivars with native Spanish cultivars and cultivars from the main breeding program based at OSU in the United States, from which several cultivars have been released (McCluskey et al., 1997, 2001, 2009; Mehlenbacher, 1995, 2007), most of them with high resistant to eastern filbert blight (Anisogramma anomala), the major fungal disease in this country (Thompson et al., 1996).
Hazelnut characteristics vary between cultivars and also according to the environment. Trials assessing cultivars from around the world, in specific climates and soil conditions, have been carried out in different countries: Australia (Baldwin, 2009; Baldwin et al., 2001, 2005), Croatia (Miljkovic, 1994), Chile (Ellena et al., 2014; Grau and Bastias, 2005; Grau et al., 2001), Italy (Baratta et al., 1994; Cristofori et al., 2014), The Netherlands (Wertheim, 1994), Portugal (Santos et al., 1994), Romania (Turcu and Botu, 1997), Slovenia (Solar and Stampar, 1997, 2009), the U.S. (McCluskey et al., 2001, 2005), and Serbia (Miletic et al., 1997). These trials are useful to know the behavior and adaptability of the cultivars in different areas of hazelnut production. The results are important for both researchers and growers because the outcome can help to decide the best cultivars to plant in new orchards. Our results show the performance of the three cultivars from OSU, compared with eight Mediterranean cultivars from Italy (four) and Spain (four), in the same environmental conditions.

\section{Materials and methods}

Material. In 2001, a hazelnut comparative trial was established at IRTA-Mas de Bover, Constantí [Tarragona, northeastern Spain (lat. $41^{\circ} 10^{\prime} 9^{\prime \prime} \mathrm{N}$, long. $1^{\circ} 10^{\prime} 28^{\prime \prime} \mathrm{E}$, altitude $110 \mathrm{~m}$ )], an area with a Mediterranean coastal climate. Over the trial period (2001-14), the average of absolute monthly maximum and minimum temperatures were 26.5 and $4.8{ }^{\circ} \mathrm{C}$, respectively, with $15.8{ }^{\circ} \mathrm{C}$ being the average monthly temperature. Average annual rainfall and reference evapotranspiration (Eto) for

\begin{tabular}{llll}
\hline $\begin{array}{l}\text { Units } \\
\begin{array}{l}\text { To convert U.S. to SI, } \\
\text { multiply by }\end{array}\end{array}$ & U.S. unit & SI unit & $\begin{array}{l}\text { To convert SI to U.S., } \\
\text { multiply by }\end{array}$ \\
\hline 0.4047 & $\mathrm{acre}(\mathrm{s})$ & $\mathrm{ha}$ & 2.4711 \\
29.5735 & $\mathrm{fl} \mathrm{oz}$ & $\mathrm{mL}$ & 0.0338 \\
0.3048 & $\mathrm{ft}$ & $\mathrm{m}$ & 3.2808 \\
0.0283 & $\mathrm{ft}^{3}$ & $\mathrm{~m}^{3}$ & 35.3147 \\
2.54 & inch(es) & $\mathrm{cm}$ & 0.3937 \\
25.4 & inch(es) & $\mathrm{mm}$ & 0.0394 \\
6.4516 & inch & $\mathrm{cm}^{2}$ & 0.1550 \\
0.4536 & $\mathrm{lb}$ & $\mathrm{kg}$ & 2.2046 \\
0.0703 & $\mathrm{lb} / \mathrm{inch}^{2}$ & $\mathrm{~kg} \cdot \mathrm{cm}^{-2}$ & 14.2233 \\
28.3495 & $\mathrm{oz}$ & $\mathrm{g}$ & 0.0353 \\
0.9072 & ton $(\mathrm{s})$ & $\mathrm{t}$ & 1.1023 \\
$\left({ }^{\circ} \mathrm{F}-32\right) \div 1.8$ & ${ }^{\circ} \mathrm{F}$ & ${ }^{\circ} \mathrm{C}$ & $\left({ }^{\circ} \mathrm{C} \times 1.8\right)+32$ \\
& & &
\end{tabular}

Hort lechnology · October 2017 27(5) 
this period were $579 \pm 131$ and $1039 \pm$ $31 \mathrm{~mm}$, respectively. The trial was established in a loamy-sandy soil texture (U.S. Department of Agriculture), classified as Typic Xeropsamments (Comisión del Banco de Datos de Suelos y Aguas, 1983). It is an alkaline soil $\mathrm{pH}(>8)$, with low organic matter content $(1 \%$ of $0-50 \mathrm{~cm})$ and medium-high active lime content $(>7 \%)$, without excess of salinity and low or very low phosphorus and potassium content.

One-year-old rooted plants were propagated by the tie-off layering method and planted at a spacing of $6 \times 3.5 \mathrm{~m}$ in a single-trunk system. Trees received fertilizers recommended for this species (Tous et al., 1994), and drip irrigation was calculated each year according the methodology proposed by Allen et al. (1998). Eleven own-rooted cultivars were chosen (Table 1): 'Clon La Masó', 'Negret N-9' [a clonal IRTA selection (Rovira et al., 2006)], 'Negret Primerenc', and 'Pauetet' from the Tarragona area in Spain (Tasias,
1975); 'San Giovanni', 'Tonda di Giffoni', 'Tonda Romana' (Manzo and Tamponi, 1982), and 'Tonda Italiana' from Italy (this last one, an IRTA selection from Italian material); and 'Clark', 'Lewis', and 'Willamette' from the hazelnut breeding program at OSU (Mehlenbacher et al., 1991, 2000, 2001).

Agronomic characteristics. The following measurements were evaluated annually over a 9-year pe$\operatorname{riod}(2003-11)$ : the number of suckers (basal shoots), trunk cross-sectional area [TCSA (square centimeters)] measured at $20 \mathrm{~cm}$ above ground level, tree height (centimeters), tree diameter (centimeters), canopy volume (cubic meters), nut yield (kilograms), and yield efficiency (total yield per square centimeter of TCSA) calculated in 2011. This was the year when the trees reached the maximum available space between trees.

Nut characteristics. Several parameters including nut weight (grams), kernel weight (grams), kernel percentage $[($ kernel weight/nut weight $)$ $\times 100$ ], kernel size $>12 \mathrm{~mm}$ (percent), and some defects [percent (blanks, shrivel and glassy appearance)] were studied each year of the trial using randomized samples of 100 nuts. These traits were studied during the period 2005-12. The ease of pellicle removal was also evaluated in 2011 , following the methodology proposed by Thompson et al. (1978). The index value of pellicle removal $\left(I_{2}\right)$ scores the percentage of kernels with more than $50 \%$ of pellicle removed.

KERNEL COMPOSITION AND NUTRITIONAL VALUE. Nutritional value (fat content, crude protein, minerals, crude fiber, total sugar, and fatty acid composition) was analyzed in 3 years $(2008,2013$, and 2014).

Moisture content was determined by heating $5 \mathrm{~g}$ of sample at $105{ }^{\circ} \mathrm{C}$ to constant weight. Fat content was analyzed by the Soxhlet method, using 5-6 g of crushed kernels (with skin) and petroleum ether

Table 1. Description of 11 hazelnut cultivars in a trial planted in 2001 , at $6 \times 3.5-\mathrm{m}(19.7 \times 11.48 \mathrm{ft})$ tree spacing, at the Institute of Agriculture and Food Research and Technology (IRTA)-Mas de Bover Station (Constantí, Spain).

\begin{tabular}{|c|c|c|c|}
\hline Cultivar & Origin & Growing area & Reported highlights \\
\hline Clark & $\begin{array}{l}\text { U.S. [Oregon State } \\
\text { University (OSU) } \\
\text { breeding program] }\end{array}$ & Oregon & $\begin{array}{l}\text { High percent kernel, kernels blanch } \\
\text { well }\end{array}$ \\
\hline Clon La Masó & Spain (Tarragona) & local cultivar & $\begin{array}{l}\text { High productivity, round nut, high } \\
\text { percent kernel }\end{array}$ \\
\hline Lewis & $\begin{array}{l}\text { U.S. (OSU breeding } \\
\text { program) }\end{array}$ & Oregon & Earlier maturity \\
\hline Negret Primerenc & Spain (Tarragona) & local cultivar & $\begin{array}{l}\text { Similar to 'Negret', more productive } \\
\text { and fruits mature earlier }\end{array}$ \\
\hline Pauetet & Spain (Tarragona) & $\begin{array}{l}\text { Tarragona and } \\
\text { southwest France }\end{array}$ & $\begin{array}{l}\text { Important in Tarragona area. High } \\
\text { productivity. Sometimes the nut is } \\
\text { mixed with 'Negret' in industry }\end{array}$ \\
\hline Tonda di Giffoni & Italy & Campania & $\begin{array}{l}\text { Well adapted to Tarragona area, nut for } \\
\text { industry, and table consumption. } \\
\text { Kernels blanch well }\end{array}$ \\
\hline Tonda Italiana & $\begin{array}{l}\text { Italy (IRTA selection from } \\
\text { Italian material) }\end{array}$ & Tarragona & High productivity \\
\hline Tonda Romana & Italy & Lazio & Appreciated for industrial uses \\
\hline Willamette & $\begin{array}{l}\text { U.S. (OSU breeding } \\
\text { program) }\end{array}$ & Oregon & $\begin{array}{l}\text { Good for blanched kernel market. } \\
\text { Excellent quality for use in pastries and } \\
\text { confectionary }\end{array}$ \\
\hline
\end{tabular}


(boiling point 40 to $60^{\circ} \mathrm{C}$ ) for $7 \mathrm{~h}$ in Soxhlet apparatus.

Crude protein was analyzed by the Kjeldahl method 950.48 (Helrick, 1990). The ground sample ( $1 \mathrm{~g}$ ) was digested using hot $96 \%$ sulfuric acid $\left(\mathrm{H}_{2} \mathrm{SO}_{4}\right)$ in a digester $(\mathrm{B}-426$; $\mathrm{Büchi}$, Flawid, Switzerland) couplet to a distiller (B-323, Büchi). Nitrogen is transformed to ammonium ion which was diluted with water and mixed with $35 \%$ sodium hydroxide $(\mathrm{NaOH})$ to produce ammonia which is distilled and loaded into an excess of $0.1 \mathrm{~N} \mathrm{H}_{2}$ $\mathrm{SO}_{4}$. Nonreacting sulfuric acid is titred with $0.1 \mathrm{~N} \mathrm{NaOH}$ using Tashiro's indicator. Protein content was computed using a 6.25 factor.

Crude fiber was measured using $\mathrm{l} \mathrm{g}$ of ground sample by adding boiling $0.26 \mathrm{~N} \mathrm{H}_{2} \mathrm{SO}_{4}(30 \mathrm{~min})$ followed by boiling $0.23 \mathrm{~N}$ potassium hydroxide $(30 \mathrm{~min})$. The extracted residue was dried at $103{ }^{\circ} \mathrm{C}(3 \mathrm{~h})$ and the dried sample weighed, put in a furnace $\left(550{ }^{\circ} \mathrm{C}\right.$ for $\left.3 \mathrm{~h}\right)$, and finally the ashes were weighed.

The mineral fraction was determined by burning $4 \mathrm{~g}$ of sample in a furnace at $550{ }^{\circ} \mathrm{C}$ for $4 \mathrm{~h}$ [AOAC method 942.05 (Helrick, 1990)].

The total sugar content was analyzed using the Luff-Schoorl method. For this, $2.5 \mathrm{~g}$ of crushed sample was extracted with ethanol $(1 \mathrm{~h})$ and then $5 \mathrm{~mL}$ of Carrez I and $5 \mathrm{~mL}$ of Carrez II solutions added ( 1 min each). After ethanol evaporation, the extract was diluted in $200 \mathrm{~mL}$ of warm water to obtain a solution were total sugars after inversion will be analyzed by the Luff-Schoorl method. In essence, this consists of boiling $25 \mathrm{~mL}$ of solution for $10 \mathrm{~min}$, adding $10 \mathrm{~mL}$ of potassium iodide and $25 \mathrm{~mL}$ of $6 \mathrm{~N} \mathrm{H}_{2} \mathrm{SO}_{4}$, and then titrating with $0.1 \mathrm{~N}$ sodium thiosulfate solution to neutralize. This value was compared with an equivalent solution, but not boiled.

Fatty acids were analyzed by gas chromatography with flame ionization detector (GC-FID) using a capillary column. The fatty acid methyl esters (FAMEs) were prepared by transesterification with $\mathrm{KOH}$, following the official method UNE-EN ISO 5509:2000. FAMEs (1 mL) were separated using a gas chromatograph (HP 6890; Agilent Technologies, Barcelona, Spain) equipped with an FID detector and a capillary column [30 $\mathrm{m} \times 0.25 \mathrm{~mm}$ i.d. (HP-Innowax, Agilent Technologies)]. The carrier gas was helium and the flow rate was $1 \mathrm{~mL} \cdot \mathrm{min}^{-1}$. The injector and detector temperatures were 220 and $275{ }^{\circ} \mathrm{C}$, respectively. The FAME identification was based on retention time relative to those of a standard FAME mixture (Sigma-Aldrich, Madrid, Spain)

Statistical analysis. For agronomic and nut characteristics, the experimental design was a randomized, complete, block with 11 cultivars, 11 replicates, and 1 tree per replicate and treatment. For nutritional values and oil composition, the experimental design was as previously mentioned, but with two replicates, one tree per replicate, and treatment for 3 years.

Analysis of variance and principal component analysis (PCA) were performed on data sets using SAS (version 9.2; SAS Institute, Cary, NC). Mean separation was using Duncan's multiple range test $(P \leq 0.05)$.

\section{Results and discussion}

Agronomic characteristics. Significant differences were found in all parameters assessed. 'Willamette' and 'Pauetet' were notable for the low number of suckers (3.4 and 4.7 suckers/tree per year, respectively). In contrast, the Italian cultivar Tonda Romana had the highest number of suckers during the years of the study (Table 2), as has been previously observed (Radicati et al., 1994). Sucker production is important in orchard management. With mechanization of cultural practices in modern orchards, the presence of suckers is a problem requiring four to five herbicide sprays per year and hand removal in winter (Tous et al., 2009). Cultivars with low sucker production are desirable in new orchards, also to reduce the environmental impact and the labor cost.

Referring to trunk cross section (square centimeters), tree height (centimeters), tree diameter (centimeters),

Table 2. Sucker production, trunk cross-sectional area (TCSA), tree height, tree diameter, and canopy volume of 11 hazelnut cultivars planted in 2001 , at $6 \times 3.5-\mathrm{m}(19.7 \times 11.48 \mathrm{ft})$ tree spacing, at the Institute of Agriculture and Food Research and Technology (IRTA)-Mas de Bover Station (Constantí, Spain).

\begin{tabular}{|c|c|c|c|c|c|}
\hline Cultivar & $\begin{array}{c}\text { Suckers } 2003-11 \\
(\text { no. } / \mathrm{yr})^{\mathrm{z}}\end{array}$ & $\begin{array}{c}\text { TCSA 2011 } \\
\left(\mathrm{cm}^{2}\right)^{\mathrm{y}}\end{array}$ & $\begin{array}{c}\text { Tree ht } 2011 \\
(\mathrm{~cm})^{\mathrm{x}}\end{array}$ & $\begin{array}{l}\text { Tree diam } \\
2011(\mathrm{~cm})\end{array}$ & $\begin{array}{l}\text { Canopy vol } \\
2011\left(\mathrm{~m}^{3}\right)^{\mathrm{x}}\end{array}$ \\
\hline Clark & $6.6 \mathrm{efg}^{\mathrm{w}}$ & $149.8 \mathrm{ab}$ & $332.7 \mathrm{bc}$ & $359.1 \mathrm{de}$ & $22.9 \mathrm{~cd}$ \\
\hline Clon La Masó & $9.9 \mathrm{~cd}$ & $178.7 \mathrm{a}$ & $292.7 \mathrm{de}$ & $410.9 \mathrm{ab}$ & $26.0 \mathrm{bc}$ \\
\hline Lewis & $11.3 \mathrm{bc}$ & $107.4 \mathrm{bc}$ & $308.8 \mathrm{~cd}$ & $350.0 \mathrm{de}$ & $19.8 \mathrm{def}$ \\
\hline Negret N-9 & $12.5 \mathrm{~b}$ & $121.3 \mathrm{~b}$ & $270.9 \mathrm{e}$ & $351.8 \mathrm{de}$ & $17.6 \mathrm{ef}$ \\
\hline Negret Primerenc & $9.5 \mathrm{~cd}$ & $72.5 \mathrm{c}$ & $239.0 \mathrm{f}$ & $346.0 \mathrm{e}$ & $15.1 \mathrm{f}$ \\
\hline Tonda di Giffoni & $6.7 \mathrm{ef}$ & $182.4 \mathrm{a}$ & $320.9 \mathrm{bc}$ & $354.1 \mathrm{de}$ & $21.2 \mathrm{cde}$ \\
\hline Tonda Italiana & $7.8 \mathrm{de}$ & $157.4 \mathrm{ab}$ & $287.0 \mathrm{de}$ & $378.0 \mathrm{~cd}$ & $21.5 \mathrm{cde}$ \\
\hline Tonda Romana & $17.1 \mathrm{a}$ & $155.8 \mathrm{ab}$ & $294.6 \mathrm{de}$ & $340.0 \mathrm{e}$ & $18.0 \mathrm{def}$ \\
\hline Willamette & $3.4 \mathrm{~g}$ & $125.8 \mathrm{~b}$ & $280.9 \mathrm{e}$ & $389.1 \mathrm{bc}$ & $22.8 \mathrm{~cd}$ \\
\hline
\end{tabular}

${ }^{\mathrm{z}}$ Mean number of suckers produced per year.

${ }^{\mathrm{y}}$ TCSA measured at $20 \mathrm{~cm}$ (7.9 inches) above the ground level; $1 \mathrm{~cm}^{2}=0.1550$ inch $^{2}$

${ }^{\mathrm{x}} \mathrm{l} \mathrm{cm}=0.3937$ inch, $1 \mathrm{~m}^{3}=35.3147 \mathrm{ft}^{3}$.

w Means within a column followed by the same letter are not significantly different by Duncan's multiple range test at $P \leq 0.05$. 
and canopy volume (cubic meters) in 2011 , the Italian cultivar San Giovanni had the highest values, with good agronomic behavior in the Tarragona climatic conditions. Previous studies have shown good performance for this cultivar in this area (Tous and Rovira, 2004). The Spanish native cultivars Negret N-9 and Negret Primerenc had the lowest values. It is known that these cultivars are very sensitive to calcareous soils (Tous et al., 2009), the type of soil in which the trial was planted.

Early bearing (years 3-5 cumulative yield after planting) was also evaluated (Table 3). For this parameter,
'San Giovanni' stood out, significantly, for the high yield (near $7 \mathrm{~kg}$ in the period 2003-05). Significant differences were also observed for the cumulative yield (2003-11). 'San Giovanni' had the highest values $(39.7 \mathrm{~kg} /$ tree), followed by 'Tonda Italiana', 'Pauetet', and 'Clon La Masó'. Cultivars with low cumulative yield were 'Tonda' 'Romana', 'Negret Primerenc', and 'Willamette'.

Cumulative yield efficiency, measured as total crop from 2003 to 2012 per trunk cross section at year 2011, was highest for the less vigorous trees. 'Negret Primerenc', 'Tonda Italiana', and 'Lewis' had the best yield efficiency (near $0.28 \mathrm{~kg} \cdot \mathrm{cm}^{-2}$ ).

Nut CHARACTERIstics. Significant differences between cultivars were found in all nut characteristics studied (Table 4). 'Tonda di Giffoni' had the highest kernel weight (1.26 g), while the Spanish 'Negret N-9', 'Negret Primerenc', and 'Pauetet' had the smallest nuts and kernels, suitable for industrial processing (Germain and Sarraquigne, 2004; Romero et al., 1997). Two cultivars had high kernel percentage (Clark and Clon La Masó), both with a very thin shell. 'Tonda di Giffoni' stood out for the kernel size, with $91.43 \%$ of

Table 3. Early bearing, cumulative yield, and yield efficiency of 11 hazelnut cultivars planted in 2001 , at $6 \times 3.5-\mathrm{m}(19.7 \times$ $11.48 \mathrm{ft}$ ) tree spacing, at the Institute of Agriculture and Food Research and Technology (IRTA)-Mas de Bover Station (Constantí, Spain).

\begin{tabular}{|c|c|c|c|}
\hline Cultivar & $\begin{array}{c}\text { Cumulative early bearing } \\
2003-05(\mathrm{~kg} / \text { tree })^{\mathrm{z}}\end{array}$ & $\begin{array}{l}\text { Cumulative total yield } \\
2003-12(\mathrm{~kg} / \text { tree })^{\mathrm{y}}\end{array}$ & $\begin{array}{l}\text { Cumulative yield } \\
\text { efficiency } 2003-12 \\
\left(\mathrm{~kg} \cdot \mathrm{cm}^{-2} \text { TCSA }\right)^{\mathrm{x}}\end{array}$ \\
\hline Clark & $3.45 \mathrm{~d}^{\mathrm{w}}$ & $24.52 \mathrm{~cd}$ & $0.17 \mathrm{~cd}$ \\
\hline Lewis & $4.87 \mathrm{c}$ & $26.49 c$ & $0.27 \mathrm{a}$ \\
\hline Negret N-9 & $2.90 \mathrm{~d}$ & $21.48 \mathrm{de}$ & $0.20 \mathrm{c}$ \\
\hline San Giovanni & $6.74 \mathrm{a}$ & $39.72 \mathrm{a}$ & $0.21 \mathrm{bc}$ \\
\hline Tonda di Giffoni & $2.98 \mathrm{~d}$ & $23.92 \mathrm{~cd}$ & $0.14 \mathrm{de}$ \\
\hline Tonda Italiana & $5.43 \mathrm{bc}$ & $37.24 \mathrm{ab}$ & $0.28 \mathrm{a}$ \\
\hline Tonda Romana & $1.70 \mathrm{e}$ & $19.59 \mathrm{e}$ & $0.15 \mathrm{de}$ \\
\hline Willamette & $2.91 \mathrm{~d}$ & $13.99 \mathrm{f}$ & $0.12 \mathrm{e}$ \\
\hline
\end{tabular}

${ }^{\mathrm{z}}$ Total crop per tree from 2003 to $2005 ; 1 \mathrm{~kg}=2.2046 \mathrm{lb}$.

'Total crop per tree from 2003 to 2012 .

${ }^{x}$ Total crop per tree from 2003 to 2012 related to trunk cross-sectional area (TCSA), measured at $20 \mathrm{~cm}(7.9$ inches) above the ground level, at the end of the year 2011 ; $1 \mathrm{~kg} \cdot \mathrm{cm}^{-2}=14.2233 \mathrm{lb} /$ inch $^{2}$.

${ }^{w}$ Means within a column followed by the same letter are not significantly different by Duncan's multiple range test at $P \leq 0.05$.

Table 4. Nut and kernel weight, kernel percentage, kernel size [ $>12 \mathrm{~mm}(0.47 \mathrm{inch})]$, defects, and roasting, of 11 hazelnut cultivars planted in 2001 , at $6 \times 3.5-\mathrm{m}(19.7 \times 11.48 \mathrm{ft})$ tree spacing, at the Institute of Agriculture and Food Research and Technology (IRTA)-Mas de Bover Station (Constantí, Spain). Mean values from 2005 to 2012.

\begin{tabular}{|c|c|c|c|c|c|c|}
\hline Cultivar & Nut wt $(g)^{z}$ & Kernel wt (g) & $\begin{array}{c}\text { Kernel } \\
\text { percentage }(\%)^{y}\end{array}$ & Kernels >12 mm (\%) & Defects $(\%)^{\mathrm{x}}$ & $\begin{array}{c}\text { Roasting } \\
I_{2} 2011(\%)^{\mathrm{n}}\end{array}$ \\
\hline Clark & $2.25 \mathrm{~d}^{\mathrm{v}}$ & $1.15 \mathrm{c}$ & $50.86 \mathrm{a}$ & $88.70 \mathrm{ab}$ & $9.38 \mathrm{~b}$ & $97 \mathrm{a}$ \\
\hline Lewis & $2.31 \mathrm{~d}$ & $1.07 \mathrm{e}$ & $46.34 \mathrm{f}$ & $75.67 \mathrm{c}$ & $9.78 \mathrm{ab}$ & $80 \mathrm{ab}$ \\
\hline Negret N-9 & $2.01 \mathrm{f}$ & $0.99 \mathrm{f}$ & $49.14 \mathrm{c}$ & $54.55 \mathrm{e}$ & $7.77 \mathrm{~b}$ & $97 \mathrm{a}$ \\
\hline Negret Primerenc & $1.86 \mathrm{~g}$ & $0.92 \mathrm{~g}$ & $49.52 \mathrm{c}$ & $28.16 \mathrm{f}$ & $8.49 \mathrm{~b}$ & $91 \mathrm{ab}$ \\
\hline Tonda di Giffoni & $2.72 \mathrm{~b}$ & $1.26 \mathrm{a}$ & $46.14 \mathrm{f}$ & $91.43 \mathrm{a}$ & $9.97 \mathrm{ab}$ & $95 \mathrm{a}$ \\
\hline Tonda Italiana & $2.78 \mathrm{a}$ & $1.07 \mathrm{e}$ & $38.21 \mathrm{~g}$ & $76.33 \mathrm{c}$ & $9.36 \mathrm{~b}$ & $90 \mathrm{ab}$ \\
\hline Tonda Romana & $2.48 \mathrm{c}$ & $1.17 \mathrm{c}$ & $46.96 \mathrm{e}$ & $89.18 \mathrm{ab}$ & $7.67 \mathrm{~b}$ & $60 \mathrm{~cd}$ \\
\hline Willamette & $2.47 \mathrm{c}$ & $1.20 \mathrm{~b}$ & $48.27 \mathrm{~d}$ & $84.82 \mathrm{~b}$ & $8.82 \mathrm{~b}$ & $90 \mathrm{ab}$ \\
\hline
\end{tabular}

${ }^{\mathrm{z}} 1 \mathrm{~g}=0.0353 \mathrm{oz}$.

$\mathrm{y}($ kernel weight $/$ nut weight $) \times 100$

${ }^{x}$ Blanks, shrivel and glassy appearance kernels

${ }^{\mathrm{w}} I_{2}=$ percentage of kernels with more than $50 \%$ of pellicle removed (Thompson et al., 1978).

${ }^{v}$ Means within a column followed by the same letter are not significantly different by Duncan's multiple range test at $P \leq 0.05$ 
nuts $>12 \mathrm{~mm}$. The results of the nut characteristics for 'Negret N-9', 'San Giovanni', 'Tonda di Giffoni', and 'Tonda Romana' were similar to those proposed by other authors (Cristofori et al., 2008; Manzo and Tamponi, 1982) for the same cultivars. However, values of nut and kernel weight of 'Tonda di Giffoni' and 'Tonda Romana' were higher than those reported by Farinelli et al. (2001) in Umbria (Italy), but lower than those observed by Ciarniello et al. (2014). Nut traits for 'Clark' were in agreement with the results obtained by Germain and Sarraquigne (2004) and Mehlenbacher et al. (2001). The characteristics of 'Pauetet' and 'Willamette' were also similar to those proposed by Germain and Sarraquigne (2004) and McCluskey et al. (2005), respectively. However, values of nut and kernel weight and kernel percentage of 'Lewis' were lower than those proposed for that cultivar by Germain and Sarraquigne (2004) and Mehlenbacher et al. (2000). Results of nut weight and kernel percentage of the three cultivars from the OSU hazelnut breeding program (Clark,
Lewis and Willamette) were similar to those obtained by Solar and Stampar (2009) in a trial with cultivars from Oregon in northeastern Slovenia.

Three cultivars, Negret N-9, Tonda di Giffoni, and Clark, were outstanding for their ease of pellicle removal after roasting. The $I_{2}$ calculated values, were, for all of them, higher than $94 \%$. 'Willamette' also scored a high value, according to Mehlenbacher et al. (1991), but in disagreement with observations of Ciarniello et al. (2014). This is an

Table 5. Nutritional composition of 11 hazelnut cultivars $(n=6)$, planted in 2001 , at $6 \times 3.5-\mathrm{m}(19.7 \times 11.48 \mathrm{ft})$ tree spacing, at the Institute of Agriculture and Food Research and Technology (IRTA)-Mas de Bover Station (Constantí, Spain). Mean values from crops 2008,2013 , and 2014.

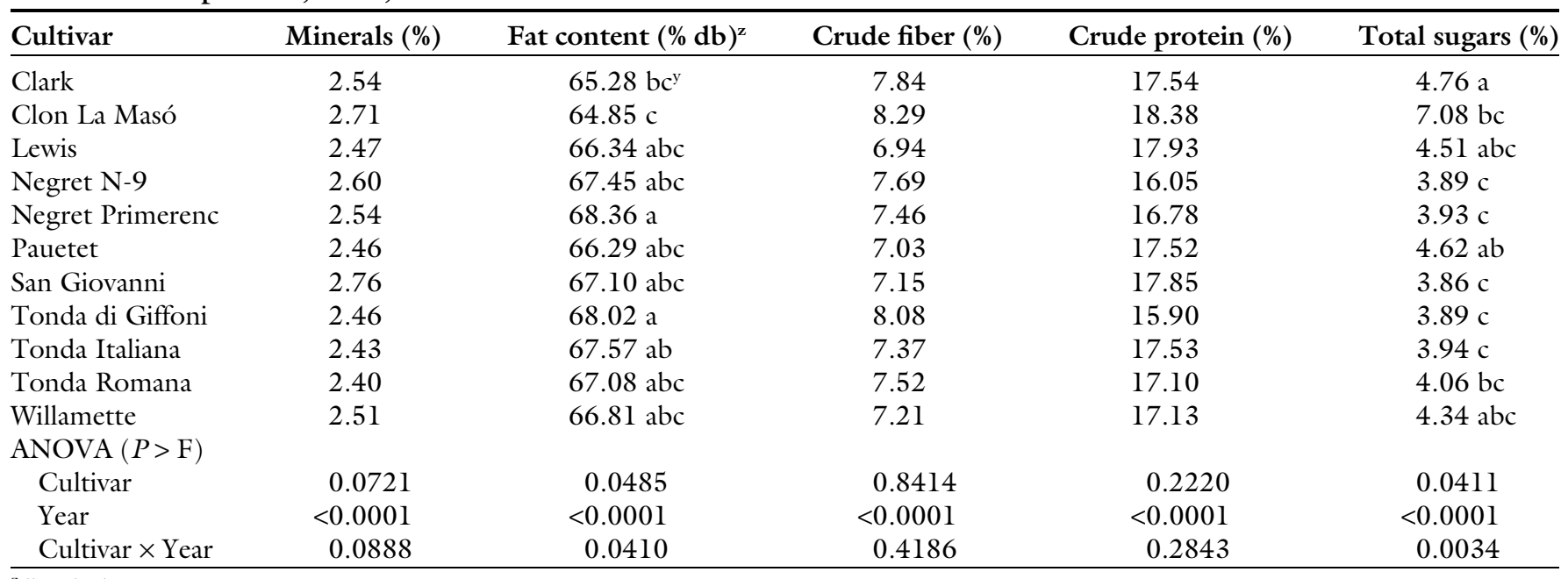

${ }^{\mathrm{z}} \mathrm{db}=$ dry basis.

${ }^{\mathrm{y}}$ Means within a column followed by the same letter are not significantly different by Duncan's multiple range test at $P \leq 0.05$.

Table 6. Major fatty acid composition $(\%)$ of 11 hazelnut cultivars $(n=6)$ planted in 2001 , at $6 \times 3.5-\mathrm{m}(19.7 \times 11.48 \mathrm{ft})$ tree spacing, at the Institute of Agriculture and Food Research and Technology (IRTA)-Mas de Bover Station (Constantí, Spain). Mean values from crops 2008,2013 , and 2014.

\begin{tabular}{|c|c|c|c|c|c|c|c|c|}
\hline \multirow[b]{2}{*}{ Cultivar } & \multicolumn{8}{|c|}{ Major fatty acid composition $(\%)^{\mathrm{z}}$} \\
\hline & C16:0 & C18:0 & C18:1 & C18:2 & SAT & INSAT & MUFA & PUFA \\
\hline Clark & $5.88 \mathrm{ab}^{\mathrm{y}}$ & $1.73 \mathrm{bc}$ & $79.77 \mathrm{bc}$ & $11.79 \mathrm{bc}$ & 8.34 & 92.17 & $80.29 \mathrm{bc}$ & $11.88 \mathrm{bc}$ \\
\hline Lewis & $5.63 \mathrm{bc}$ & $1.73 \mathrm{bc}$ & $80.81 \mathrm{abc}$ & $11.04 \mathrm{bc}$ & 7.58 & 92.42 & $81.29 \mathrm{abc}$ & $11.12 \mathrm{bc}$ \\
\hline Negret N-9 & $5.51 \mathrm{bc}$ & $1.78 \mathrm{abc}$ & $78.79 \mathrm{c}$ & $11.78 \mathrm{bc}$ & 9.17 & 90.83 & $78.98 \mathrm{c}$ & $11.86 \mathrm{bc}$ \\
\hline Negret Primerenc & $8.77 \mathrm{abc}$ & $1.58 \mathrm{c}$ & $75.64 \mathrm{~d}$ & $16.24 \mathrm{a}$ & 7.87 & 92.43 & $76.13 \mathrm{~d}$ & $16.31 \mathrm{a}$ \\
\hline Tonda di Giffoni & $5.43 \mathrm{c}$ & $2.00 \mathrm{ab}$ & $82.08 \mathrm{ab}$ & $9.74 \mathrm{bc}$ & 7.65 & 92.35 & $82.53 \mathrm{ab}$ & $9.82 \mathrm{bc}$ \\
\hline Tonda Italiana & $5.63 \mathrm{bc}$ & $1.90 \mathrm{ab}$ & $82.71 \mathrm{a}$ & $8.98 \mathrm{c}$ & 7.77 & 92.23 & $83.18 \mathrm{a}$ & $9.05 \mathrm{c}$ \\
\hline Tonda Romana & $6.08 \mathrm{a}$ & $1.99 \mathrm{ab}$ & $80.89 \mathrm{abc}$ & $10.25 \mathrm{bc}$ & 8.29 & 91.70 & $81.37 \mathrm{abc}$ & $10.33 \mathrm{bc}$ \\
\hline Willamette & $5.77 \mathrm{abc}$ & $2.06 \mathrm{a}$ & $82.04 \mathrm{ab}$ & $9.32 \mathrm{bc}$ & 8.07 & 91.93 & $82.53 \mathrm{ab}$ & $9.40 \mathrm{bc}$ \\
\hline \multicolumn{9}{|l|}{$\operatorname{ANOVA}(P>\mathrm{F})$} \\
\hline
\end{tabular}

${ }^{\mathrm{z}} \mathrm{Cl6}$ :0 = palmitic acid; C18:0 = stearic acid; C18:1 = oleic acid; C18:2 = linoleic acid; SAT = saturated fatty acids; INSAT = unsaturated fatty acids; MUFA = monounsaturated fatty acids; PUFA = polyunsaturated fatty acids.

${ }^{\mathrm{y}}$ Means within a column followed by the same letter are not significantly different by Duncan's multiple range test at $P \leq 0.05$. 
Table 7. Minor fatty acids composition $(\%)$ of 11 hazelnut cultivars $(n=6)$ planted in 2001 , at $6 \times 3.5-\mathrm{m}(19.7 \times 11.48 \mathrm{ft})$ tree spacing, at the Institute of Agriculture and Food Research and Technology (IRTA)-Mas de Bover Station (Constantí, Spain). Mean values from crops 2008,2013 , and 2014.

\begin{tabular}{|c|c|c|c|c|c|c|c|}
\hline \multirow[b]{2}{*}{ Cultivar } & \multicolumn{7}{|c|}{ Minor fatty acid composition (\%) } \\
\hline & C14:0 & C16:1 & C17:0 & C17:1 & C18:3 & C20:0 & C20:1 \\
\hline Clark & $0.038 \mathrm{a}^{\mathrm{y}}$ & $0.280 \mathrm{a}$ & 0.037 & 0.073 & $0.082 \mathrm{bc}$ & $0.110 \mathrm{~b}$ & $0.165 \mathrm{a}$ \\
\hline Lewis & $0.034 \mathrm{abcd}$ & $0.238 \mathrm{bc}$ & 0.038 & 0.075 & $0.080 \mathrm{bc}$ & $0.110 \mathrm{~b}$ & $0.167 \mathrm{a}$ \\
\hline Negret N-9 & $0.031 \mathrm{~d}$ & $0.243 \mathrm{~b}$ & 0.037 & 0.072 & $0.075 \mathrm{c}$ & $0.112 \mathrm{~b}$ & $0.172 \mathrm{a}$ \\
\hline Negret Primerenc & $0.032 \mathrm{~cd}$ & $0.257 \mathrm{ab}$ & 0.035 & 0.072 & $0.074 \mathrm{c}$ & $0.097 \mathrm{c}$ & $0.160 \mathrm{ab}$ \\
\hline Tonda di Giffoni & $0.025 \mathrm{e}$ & $0.217 \mathrm{c}$ & 0.040 & 0.073 & $0.078 \mathrm{c}$ & $0.113 \mathrm{~b}$ & $0.160 \mathrm{ab}$ \\
\hline Tonda Italiana & $0.033 \mathrm{bcd}$ & $0.242 \mathrm{~b}$ & 0.040 & 0.075 & $0.072 \mathrm{c}$ & $0.108 \mathrm{~b}$ & $0.158 \mathrm{ab}$ \\
\hline Tonda Romana & $0.034 \mathrm{abcd}$ & $0.280 \mathrm{ab}$ & 0.040 & 0.072 & $0.077 \mathrm{c}$ & $0.112 \mathrm{~b}$ & $0.150 \mathrm{~b}$ \\
\hline Willamette & $0.036 \mathrm{abc}$ & $0.243 \mathrm{~b}$ & 0.040 & 0.077 & $0.078 \mathrm{c}$ & $0.128 \mathrm{a}$ & $0.168 \mathrm{a}$ \\
\hline \multicolumn{8}{|l|}{$\operatorname{ANOVA}(P>\mathrm{F})$} \\
\hline
\end{tabular}

${ }^{\mathrm{z}} \mathrm{Cl4}: 0$ = myristic acid; $\mathrm{Cl} 6: 1$ = palmitoleic acid; $\mathrm{Cl7}: 0$ = magaric acid; $\mathrm{Cl}$ : 1 = marganoleic acid; $\mathrm{Cl}$ : $3=$ linolenic acid; $\mathrm{C} 20: 0=$ arachidic acid; $\mathrm{C} 20: 1=$ gadoleic acid ${ }^{\mathrm{y}}$ Means within a column followed by the same letter are not significantly different by Duncan's multiple range test at $P \leq 0.05$.

interesting trait for industrial processing (Di Matteo et al., 2012). Referring to kernel defects, few significant differences between cultivars were observed.

In trials on hazelnut cultivar performance, Tonda di Giffoni has been showed to have the widest adaptability of the genotypes evaluated in southeastern Australia (Baldwin, 2009; Baldwin et al., 2005) and the southeastern region of Slovenia (Solar and Stampar, 1997). Adaptability of this Italian cultivar in our conditions was also good. In the last 15 years, most of the new hazelnut orchards in Tarragona area have Tonda di Giffoni as the main cultivar (M. Rovira, unpublished data).

Nutritional VALUES AND OIL Composition. Differences between cultivars were observed for fat and total sugar contents (Table 5 ). In addition, a major influence of the year was observed for all the compounds, and the interaction with cultivar was less meaningful. In the sense that no crossed effects were observed and only in one of the years the relative differences between cultivars were higher than in the others. Fat content ranged from $64.85 \%$ dry basis $(\mathrm{db})$ in 'Clon $\mathrm{La}$ Masó' to $68.36 \% \mathrm{db}$ in 'Negret Primerenc'. These values are generally higher than those reported elsewhere (Cristofori et al., 2008; Parcerisa et al., 1995; Tous et al.,

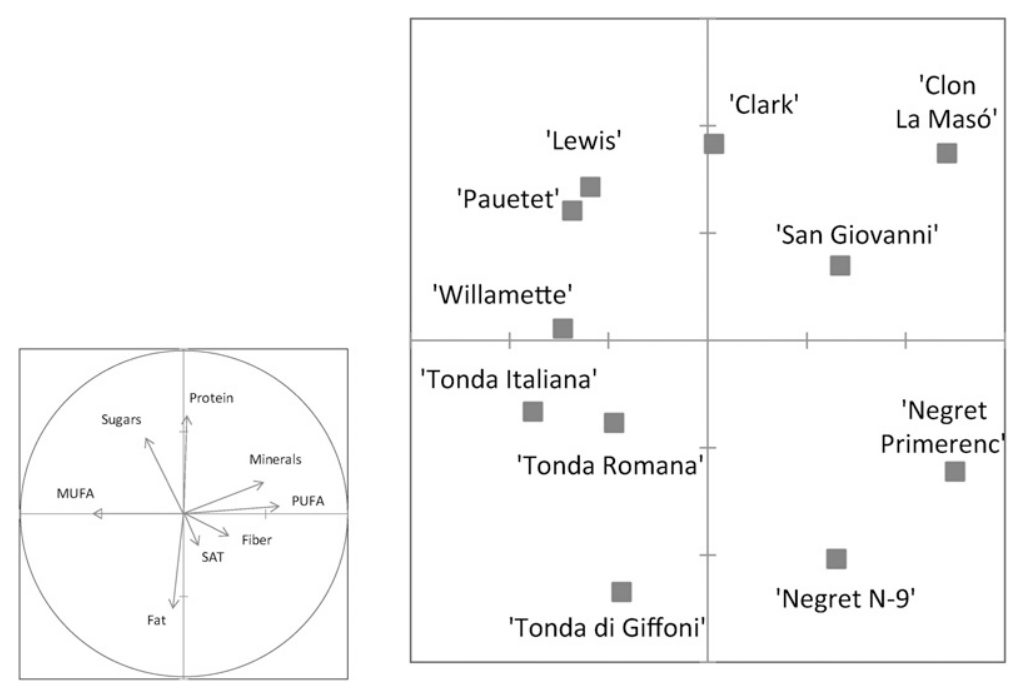

Fig. 1. Eigenvectors (left) from principal component (PC) analysis for hazelnut nutritional value (circle denotes correlation $=1$ ). Biplot (right) of two first PCs for nutritional value [first PC (PRIN1) in the horizontal axis retains 32\% of total variability; second PC (PRIN2) in the vertical axis explains $28 \%$ ].

2001), even though relative differences between cultivars are the same, but the fat content of 'Tonda Romana' and 'Tonda di Giffoni' were slightly lower than those published by Farinelli et al. (2001).

Total sugars content ranged from $3.86 \%$ in 'San Giovanni' to $7.08 \%$ in 'Clon La Masó'. Relative differences between the cultivars were equivalent to those reported by Cristofori et al. (2008), but the mean values were lower in our study.
Fatty acid composition (Tables 6 and 7) was significantly different, depending on the cultivar and the characteristics of the year. Interaction cultivar $\times$ year was significant for many compounds, but did not affect the mean value of each cultivar because these values were more related to the fact that variations between years were higher in some cultivars. For instance, the group of Spanish cultivars (Clon La Masó, Negret N-9, Negret Primerenc, and 
Pauetet) had up to $10 \%$ variation in oleic acid content between years, while the other cultivars only varied $5 \%$ to $7 \%$. The cultivar richest in polyunsaturated fatty acids (PUFAs) was Negret Primerenc (16.31\%) while 'Tonda Italiana' was the poorest (9.05\% in average). In general, PUFA had the highest variability with $23 \%$ of $\mathrm{CV}$, while minor fatty acids were less variable (lower than $10 \% \mathrm{CV}$ ), although there were some significant differences between cultivars and years for these compounds (Table $6)$. The observed values were very similar to those reported by Cristofori et al. (2008), Farinelli et al. (2001), Parcerisa et al. (1995), and Tous et al. (2001).

No differences between cultivars were observed for mineral content, crude fiber, or crude protein, although there were significant variations between years.

PCA showed (Fig. 1) that the main differences in nutritional composition between the studied cultivars was related to fatty acid composition: PUFA and MUFA, which are highly correlated to first principal component (PRINl), crude protein content, correlated to positive values of second principal component (+PRIN2) and fat content, and correlated to negative values of second principal component (-PRIN2). Four different groups with a similar composition could be highlighted: the "Negret" group ('Negret N-9', 'Negret Primerenc'); "Tonda" group ('Tonda di Giffoni', 'Tonda Italiana', 'Tonda Romana'); a third group with 'Lewis', 'Pauetet', and 'Willamette'; and the last group with 'Clark', 'Clon La Masó', and 'San Giovanni'.

\section{Conclusions}

Results obtained in this hazelnut trial revealed interesting behavior of different cultivars in northeastern Spain. The best agronomic performance was observed in 'San Giovanni', 'Pauetet', 'Clon La Masó', and in 'Tonda Italiana' scoring the highest total crop and canopy volume, even though 'San Giovanni' and 'Clon La Masó' produce a high number of suckers. According to fruit traits, the kernels with the best industrial value were those of 'Tonda di Giffoni', 'Negret N-9', 'Willamette', and 'Clark' with high roasting aptitude and high fat content, even though
'Negret N-9' is a little poor in MUFA. The studied hazelnut cultivars from Oregon had good agronomic behavior and industrial potential, but were no better than the traditional Mediterranean cultivars.

\section{Literature cited}

Allen, R.G., L.S. Pereira, D. Raes, and M. Smith. 1998. Crop evapotranspiration: Guidelines for computing crop water requirements. FAO irrigation and drainage paper 56. FAO, Rome, Italy.

Baldwin, B. 2009. The effects of site and seasonal conditions on nut yield and kernel quality of hazelnut genotypes grown in Australia. Acta Hort. 845:83-88.

Baldwin, B., K. Gilchrist, and L. Snare. 2001. Variation in flowering, growth and yield of hazelnut cultivars and growers' selections in Australia. Acta Hort. 556:109-116.

Baldwin, B., K. Gilchrist, and L. Snare. 2005. An evaluation of hazelnut genotypes in Australia. Acta Hort. 686:47-56.

Baratta, B., A. Raimondo, F. Calderone, and G. Campisi. 1994. Four years of trials on comparing 45 hazelnut cultivars in the Nebrodi area (Me). Acta Hort. 351:79-92.

Ciarniello, L.F., M.F. Mazzeo, P. Minasi, A. Peluso, A. De Luca, P. Piccirillo, R.A. Siciliano, and V. Carbone. 2014. Analysis of different european hazelnut (Corylus avellana L.) cultivars: Authentication, phenotypic features, and phenolic profiles. J. Agr. Food Chem. 62:6236-6246.

Comisión del Banco de Datos de Suelos y Aguas. 1983. Sinedares, Manual para la descripción codificada de suelos en el campo. Ministerio de Agricultura, Pesca y Alimentación de España.

Cristofori, V., S. Bizarri, C. Silvestri, R. Muleo, E. Rugini, and F.R. De Salvador 2014. First evaluations on vegetative and productive performance of many hazelnut cultivars in Latium region. Acta Hort. 1052:91-97.

Cristofori, V., S. Ferramondo, G. Bertazza, and C. Bignami. 2008. Nut and kernel traits and chemical composition of hazelnut (Corylus avellana L.) cultivars. J. Sci. Food Agr. 88:1091-1098.

Di Matteo, M., D. Albanese, and L. Liguori. 2012. Alternative method for hazelnut peeling. Food Bioprocess Technol. 5:14161421 .

Ellena, M., P. Sandoval, A. Gonzalez, J. Jequier, and M. Contreras. 2014. Preliminary results of some nut characteristics within 'Chilean Barcelona' hazelnut cul- tivar in south Chile. Acta Hort. 1052:85-89.

Farinelli, D., A. Tombesi, M. Boco, and C.S. Trappoloni. 2001. Hazelnut (Corylus avellana L.) kernel quality during maturity in central Italy. Acta Hort. 556:553-558.

Food and Agriculture Organization of the United Nations. 2017. FAOSTAT. 20 Jan. 2017. <http://www.fao.org/ faostat/es/\#data/QC>.

Garcia, M.D., J. Mena, and J. Clavé. 1983. Observations on hazelnut cultivars from Tarragona (Spain) compared with Italian varieties. Atti del Convegno Internationale sul Nocciuolo. Assessorato Agricoltura Regione Campania, Avellino. p. 383-386.

Germain, E. and J.P. Sarraquigne. 2004. Le noisetier. Centre Technique Interprofessionel des Fruits et Légumes, París, France.

Grau, P. and R. Bastias. 2005. Productivity and yield efficiency of hazelnut (Corylus avellana L.) cultivars in Chile. Acta Hort. 686:57-64.

Grau, P., A. France, M. Gerding, A. Lavín, and A. Torres. 2001. Preliminary evaluation of hazelnut performance in Chile. Acta Hort. 556:49-57.

Helrick, K. (ed.). 1990. Official methods of analysis of the Association of Official Analytical Chemists. 15th ed. Assn. Official Anal. Chemists, Arlington, VA.

Manzo, P. and G. Tamponi. 1982. Monografia di cultivar di nocciuolo. Istituto Sperimetale per la Frutticoltura, Rome, Italy.

McCluskey, R.L., A.N. Azarenco, S.A. Mehlenbacher, and D.C. Smith. 1997. Performance of hazelnut cultivars and Oregon State University breeding selections. Acta Hort. 445:13-19.

McCluskey, R.L., A.N. Azarenco, S.A. Mehlenbacher, and D.C. Smith. 2001. Commercial hazelnut cultivar and advanced selection evaluations at Oregon State University. Acta Hort. 556:89-95.

McCluskey, R.L., A.N. Azarenco, S.A. Mehlenbacher, and D.C. Smith. 2005. Advanced selection and cultivar performance of hazelnut trials planted in 1994 and 1998 at Oregon State University. Acta Hort. 686:71-78.

McCluskey, R.L., S.A. Mehlenbacher, D.C. Smith, and A.N. Azarenco. 2009. Advanced selection and new cultivar performance in hazelnut trials planted in 1998 and 2000 at Oregon State University. Acta Hort. 845:67-71.

Mehlenbacher, S.A. 1995. Progress in breeding new hazelnut cultivars in Oregon. FAO-CIHEAM Nut Network. Nucis Nwsl. 3:8-9. 
Mehlenbacher, S.A. 2007. Hazelnut breeding an update from Oregon. FAO-CIHEAM Nut Network Nucis Nwsl. 14:9-10.

Mehlenbacher, S.A., A.N. Azarenco, D.C. Smith, and R.L. McCluskey. 2000. 'Lewis' hazelnut. HortScience 35:314-315.

Mehlenbacher, S.A., A.N. Azarenko, D.C. Smith, and R. McCluskey. 2001 . 'Clark' hazelnut. HortScience 36:995996.

Mehlenbacher, S.A., A.N. Miller, M.M. Thompson, H.B. Lagerstedt, and D.C. Smith. 1991. 'Willamette' hazelnut. HortScience 26:1341-1342.

Miletic, R., D. Ogasanovic, M. Mitrovic, and R. Plazinic. 1997. Results of investigating some hazelnut (Corylus avellana L.) cultivars in arid conditions. Acta Hort. 445:73-78.

Miljkovic, I. 1994. Behaviour of eight hazelnut cultivars in Istra (Croatia). Acta Hort. 351:99-110.

Ministerio de Agricultura y Pesca, Alimentación y Medio Ambiente. 2017. Anuario de estadística 2015. 20 Jan. 2017. <http://www.mapama.gob.es/ es/estadistica/temas/publicaciones/ anuario-de-estadistica $/ 2015 /$ default. aspx? parte $=3 \&$ capitulo $=13 \&$ grupo $=10 \&$ $\sec$ ion $=2>$.

Parcerisa, J., J. Boatella, R. Codony, M. Rafecas, A.J. Castellote, A. López, and A. Romero. 1995. Comparison of fatty acid and triacylglycerol composition of different hazelnut varieties (Corylus avellana L.) cultivated in Catalonia (Spain). J. Agr. Food Chem. 42:13-16.
Radicati, L., I. Martino, and G. Vergano. 1994. Factors affecting sucker production in hazelnut. Acta Hort. 351:489-494.

Romero, A., J. Tous, J. Plana, I. Díaz, J. Boatella, J. García, and A. López. 1997. Commercial quality characterization of Spanish 'Negret' cultivar. Acta Hort. 445:157-163.

Rovira, M., J. Tous, and J. Aramburu. 2006. El clon de avellano 'Negret IRTA-N.9'. Vida Rural 232(13):18-20.

Santos, A., A.P. Silva, and J. Colaço. 1994. Annual growth dynamics of eleven hazelnut varieties in northern Portugal. Acta Hort. 351:93-98.

Solar, A. and F. Stampar. 1997. First experiences with some foreign hazelnut cultivars (Corylus avellana L.) in Slovenia. Acta Hort. 445:83-89.

Solar, A. and F. Stampar. 2009. Performance of hazelnut cultivars from Oregon in northeastern Slovenia. HortTechnology 19:653-659.

Tasias, J. 1975. El avellano en la provincia de Tarragona. Excma. Diputación Provincial de Tarragona, Tarragona, Spain.

Thompson, M.M., H.B. Lagerstedt, and S.A. Mehlenbacher. 1996. Hazelnuts, p. 125-184. In: J. Janick and J.N. Moore (eds.). Fruit breeding. Vol. 3, Nuts. Wiley, New York, NY.
Thompson, M.M., P. Romisondo, E. Germain, R. Vidal-Barraquer, and J. Tasias Valls. 1978. An evaluation system for filberts (Corylus avellana L.). HortScience 13:514-517.

Tous, J., J. Girona, and J. Tasias. 1994. Cultural practices and costs in hazelnut production. Acta Hort. 351:395-418.

Tous, J., A. Romero, M. Rovira, and J.F. Hermoso. 2009. Performace of 'Negret' hazelnut cultivar grafted on 4 rootstocks in Catalonia (Spain). Acta Hort. 845:8993.

Tous, J., A. Romero, X. Sentís, J. Plana, I. Díaz, and J.F. Vargas. 2001. Influence of harvest period on hazelnut quality. Acta Hort. 556:567-573.

Tous, J. and M. Rovira. 2004. Situación y perspectivas agronómicas del cultivo del avellano. Vida Rural 201(11):41-45.

Tous, J., M. Rovira, and J. Plana. 1987. Cultivo del avellano. Fruticultura Profesional 11:115-123.

Turcu, E. and I. Botu. 1997. Behaviour of some hazelnut varieties in the subcarpathian area of Oltenia-Romania. Acta Hort. 445:135-144.

Wertheim, S.J. 1994. Hazelnut cultivar evaluation in The Netherlands. Acta Hort. 351:71-77. 